\title{
Consumer Pattern and Elderly Consumer Behavior: A Meta-Analysis
}

\author{
Vania Eugênia da Silva, Karla Maria Damiano Teixeira
}

\begin{abstract}
This study undertakes a meta-analysis of the literature to gain insight into existing empirical studies on consumption patterns and consumption behavior of elderly consumers. Web of Science platform was used as database, with a time frame starting in 2001. In addition, the VOSviewer program was used to elaborate and visualize bibliometric networks. The results suggest that there are few studies regarding the consumption pattern. There is a slightly larger number of studies with an economic focus regarding the behavior of the elderly consumers. However, these numbers are still not very expressive. Most of the studies were carried out in the business area, followed by the economics area. This meta-analysis provides comprehensive evidence to understand the behavior and perception of the elderly people in relation to credit consumption, some types of food, products developed to facilitate mobility, new household technologies, clothing, among others. In this sense, studies that aim to understand the elderly consumer, their different needs and how they manage their family budget and monthly expenses are relevant for public policies to be created and implemented to support this population.
\end{abstract}

Index Terms - Consumer behavior, Consumption pattern, Elderly people, Meta-analysis.

\section{INTRODUCTION}

Understanding the elderly people consumption is of great interest for researchers worldwide. The elderly consumer segment has become even more important since the 1980s [1] with the increasing size and buying power of elderly consumers. Therefore, the importance of the understanding of their consumption pattern and consumption behavior.

As the number of elderly people grows, so does their consumption. Besides, purchases and consumption habits change with age. As people get older, preferences and needs for products and services tend to change, as well as the spending structure and household income [2]. The contemporary elderly person not only live longer, as well as is healthier, works longer, has greater purchasing power, and consumes more and not only for necessity, but also for pleasure and fun. The self-perception of age has a great impact on the behavior of elderly consumers. The elderly people feel younger than their real age, which requires the discussion of marketing and business strategies to meet the demands of this audience [3].

Although elderly consumers have consumption needs like those of younger adults, they demonstrate more mature

Vania Eugênia da Silva, Departament of Home Economics, Federal University of Viçosa, Viçosa, Brazil

Karla Maria Damiano Teixeira, Departament of Home Economics, Federal University of Viçosa, Viçosa, Brazil consumer attitudes, play a less important role in the family, and have a strong desire for compensatory consumption [4]. There is an evident concern with the implications of population aging in the economic sphere, mainly considering macroeconomic aspects, such as the deterioration of the elderly people's health condition, workforce, social security, savings, and poverty [5]. On the other hand, microeconomic issues, such as income and consumption, allocation of family resources, family budget, consumption pattern, factors that influence consumer behavior, among others, have not yet been frequently addressed in academic research. In this context, gender, race, marital status and rural or urban residence, regardless of age and family size are other factors that influence the consumption and well-being of elderly people [6]. This article aims to systematically evaluate the published evidence regarding consumption pattern and consumption behavior of elderly consumers, in addition to identify the countries and institutions where the studies have been developed. This study can be considered as a guide for future research because of its contribution to the knowledge related to understanding the elderly consumer.

\section{METHOD}

This meta-analysis sought to answer the following question: how many articles have been published with the terms "consumption pattern" and "consumption behavior" of elderly consumers in the first two decades of the $21^{\text {st }}$ Century?

A search for articles published up to 2001 was performed on June 17, 2020 in the Web of Science platform (Main Collection), maintained by Clarivate Analytics. This platform was selected due to its international recognition. It brings together journals that have the Journal Citation Reports (JCR) index, in addition to scientific articles from other databases such as Scopus, ProQuest and Wiley.

The search for articles on the platform initially used the descriptors "consumption patterns" and "elderly", with the keywords in quotes. We opted to select articles only in English, Portuguese and Spanish, excluding works published as proceedings, papers, reviews and meeting abstracts and in other languages. Fifty-four articles were found from different areas of knowledge. Between those, 52 were in English, one in Portuguese, and one in Spanish. Among these, six were related to the Economics area, subdivided into Economics (three), Business (two), and Business Finance (one).

We then narrowed the search using the terms "consumer behavior" and "elderly", to obtain more satisfactory results with an economic bias. We found 25 articles from different areas of knowledge: 22 in English, two in Portuguese, and 
one in Spanish. From those, 12 articles had the Economics as their main area of publication. They were then subdivided into Business (nine) and Economics (three).

Analysis of the selected articles was carried out descriptively in two stages. The first stage included the research area and the reported citations. The analysis' second stage comprised the construction of networks.

The software VOSviewer 1.6.11 was used to elaborate and visualize the bibliometric networks and clusters. The networks and clusters used data such as journals of publication, papers published by the same researcher and individual publications. The networks were built based on citation relationships, bibliographic coupling, co-citation, and co-authorship. Data mining was used to build and visualize networks of co-occurrence of important terms extracted from a body of scientific literature [7].

After generating network maps and clusters we assessed the potential contribution of each map to the understanding of the relationships under analysis. Finally, we read and categorized the found articles.

\section{RESULTS AND DISCUSSION}

Fig. 1 indicates the article selection process flowchart. Initially, using the descriptors "consumption patterns" and "elderly", 68 documents were identified on the platform. After applying the selection criteria as type of document (only articles) and language, the number was reduced to 57: 52 in English, three in German, one in Portuguese and one in Spanish. The three articles in German were excluded, resulting in a selection of 54 articles to be fully read.

A second search using the descriptors "consumer behavior" and "elderly" identified 33 documents. We then narrowed the search criteria for articles, only, and encountered a reduced number of 25 documents: 22 in English, two in Portuguese, and one in Spanish. Those articles were selected to be fully read.

Fig. 2 indicates that most studies related to the consumption pattern of elderly people were related to the Nutrition, Technology and Food Science, and Gerontology areas. It also indicates the scarcity of studies focused on Economic area.

Fig. 1

Flowchart of selected scientific articles

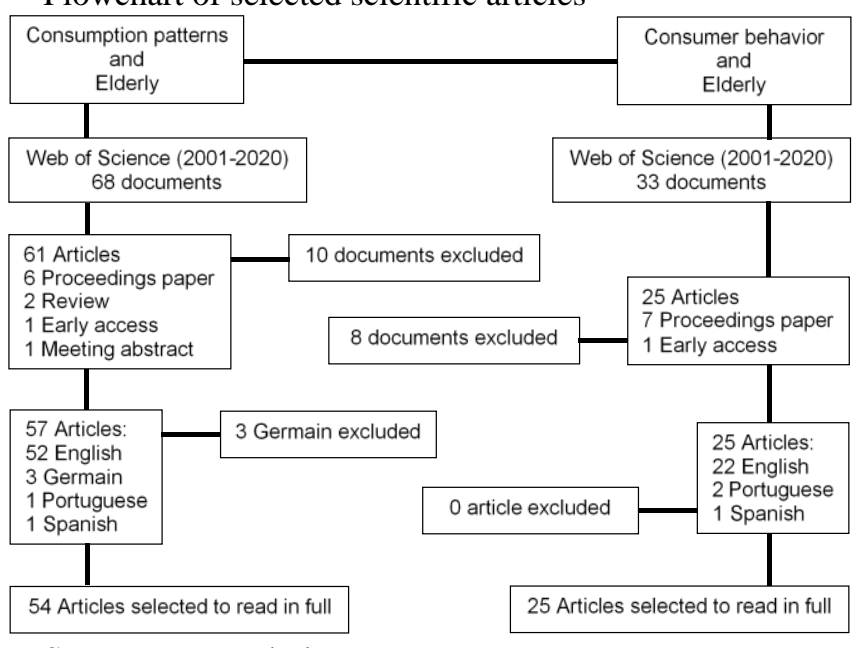

Source: Research data.
Fig 2

Number of published articles by research areas on elderly consumption pattern since 2001

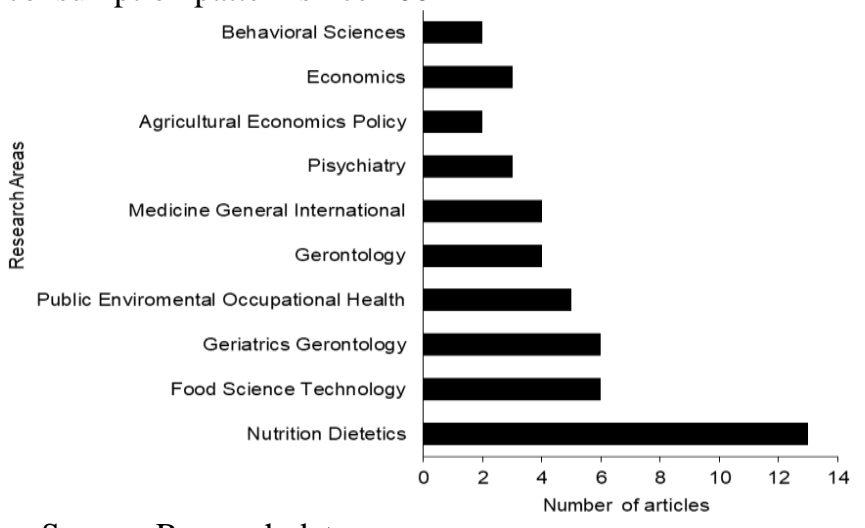

Source: Research data.

We established a minimum co-occurrence criterion of two terms or keywords related to the theme. As so, the search resulted in 419 terms, of which 62 were related to each other. Figs. 3 and 4 show the seven clusters formed by the VOSviewer software based on the most frequent terms found in the selected articles.

The keywords with the higher number of occurrences were those related to risk, health, beverages consumption, and diets (Figs. 3 and 4). The built network and the clusters show the focus given in studies on the consumption pattern of the elderly, that is, nutrition and health risks (Fig. 3).

The terms with the highest occurrences in the articles found were "risk" (11), "elderly" (10), "prevalence" (seven), and "women" (seven). Therefore, regarding the consumption pattern of the elderly people, three clusters referred to health, diet, nutrition issues, and mortality (clusters 1, 5 and 6); two were related to alcohol consumption (clusters 3 and 4); one to food consumption (cluster 2); and one (cluster 7) to diet, lifestyle, and survival of the elderly people patterns. No cluster had an economic focus.

Fig. 3

Clusters generated using the keywords "consumption patterns" and "elderly"

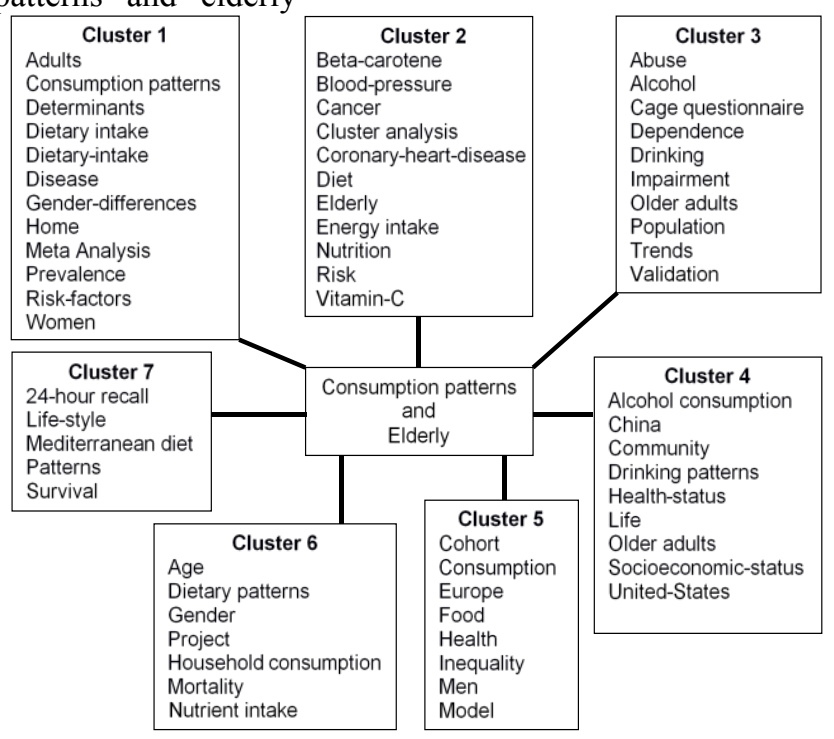

Source: Research data. 
Fig. 4

Co-occurrence of more relevant terms about the consumption pattern of the elderly

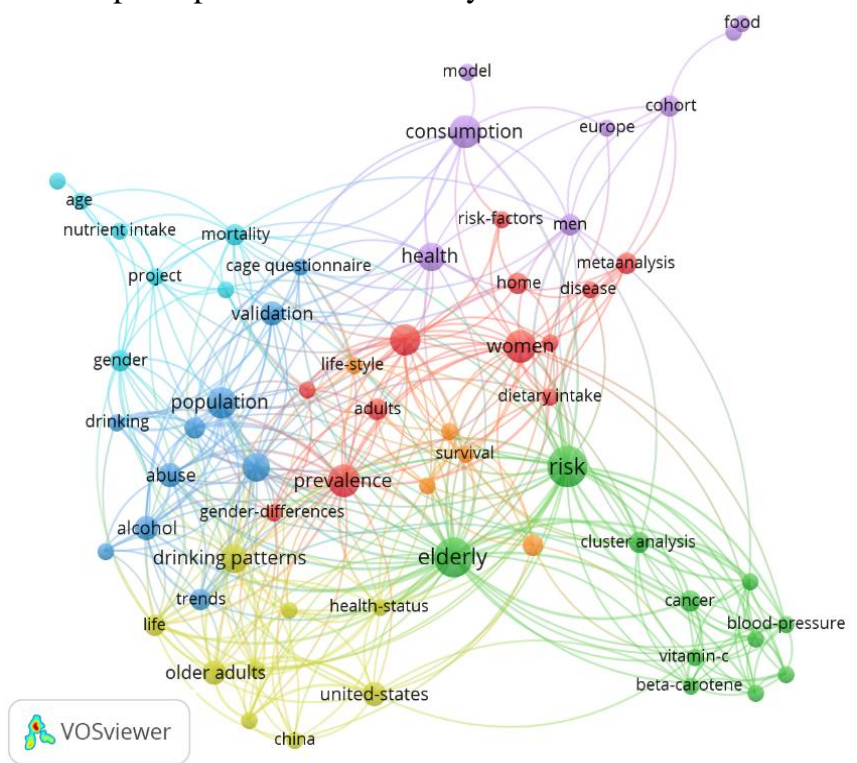

Source: Research data.

Due to the small number of studies related to the elderly consumption pattern in the Economics area, the keywords "consumer behavior" and "elderly" were included in the search. These keywords are also important to understand the elderly people's consumption pattern, as well as their buying behavior.

According to the Web of Science platform, the first internationally published study about elderly consumer behavior is from 1978 and is entitled "Consumer-behavior of elderly - Possibilities and limitations of an age-related consumer policy", written by G. Naegele [8].

From 2001 to 2004, 2006 to 2007, and 2011 to 2013 there were no published articles on the researched topic. Most of the articles were published in the years 2016 (five articles) and 2017 (six articles), as exposed on Fig. 5. There was an increase in the number of publications since 2005.

We noticed gaps over time once we considered the 25 publications found after applying the refinement criterion "type of publication". This result allows us to infer that the researched subject can still be considered incipient to the consumption field.

Fig. 5

Published studies on elderly consumer behavior since 2001

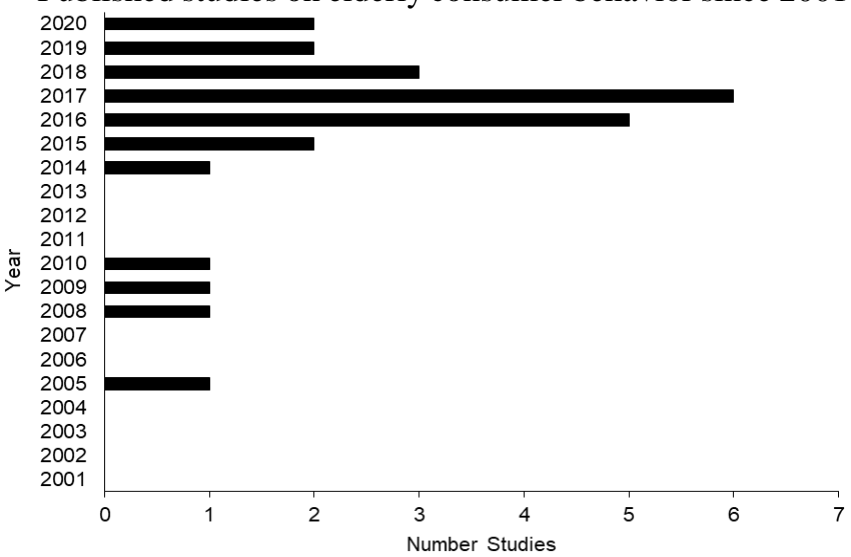

Source: Research data.
The data emphasize a lack of research related to the theme elderly consumer behavior. A reason for that may be that only after the 1980s, the elderly people started to be represented in a more positive way. Therefore, only after this decade their needs began to gain visibility. It was by this time that they also were recognized as potential consumers, and the consumer industry began to consider a new niche to optimize its profits [9].

To understand the elderly purchasing behavior, many researches have begun to emerge in the business, marketing, advertising, psychology and economics areas. Fig. 6 presents the main research areas related to the studies about elderly consumer behavior. Approximately half of the published articles $(48 \%)$ was related to the Business Economics area.

Table 1 demonstrates the articles with at least 10 citations. For the time frame adopted, each author had only one article published on the topic. This may be explained by the fact that the subject has gradually gained attention and relevance in the academic and scientific environment over the researched time lapse.

The total number of citations can be related to the year of publishing, since the most recent articles did not have an expressive number of citations in relation to the older publications. Regarding the published language, English was predominant because of the globally accessibility to the scientific content [10].

Fig. 7 demonstrates that 25 articles were related to the descriptors "consumer behavior" and "elderly", and the majority of them was categorized as Business (nine), e.g. the studies by [11], [12], [13], [14], [15], [16], [17], among others; and the Economics (three), such as the researchers [18], [19], and [20].

Of the 25 articles found, only six had more than 10 citations, ranging from 17 to 56, and four were in the Business or Economics categories, namely: [21] "Luxury purchasing among older consumers: exploring inferences about cognitive age, status, and style motivations"; [13] "Decision making and brand choice by older consumers"; [19] "A behavioral model of the elderly internet consumer: A case study"; and [22] "Virtual shopping and unconscious persuasion: The priming effects of avatar age and consumers'age discrimination on purchasing and prosocial behaviors".

Fig. 6

Number of articles published by research areas on elderly consumer behavior since 2001

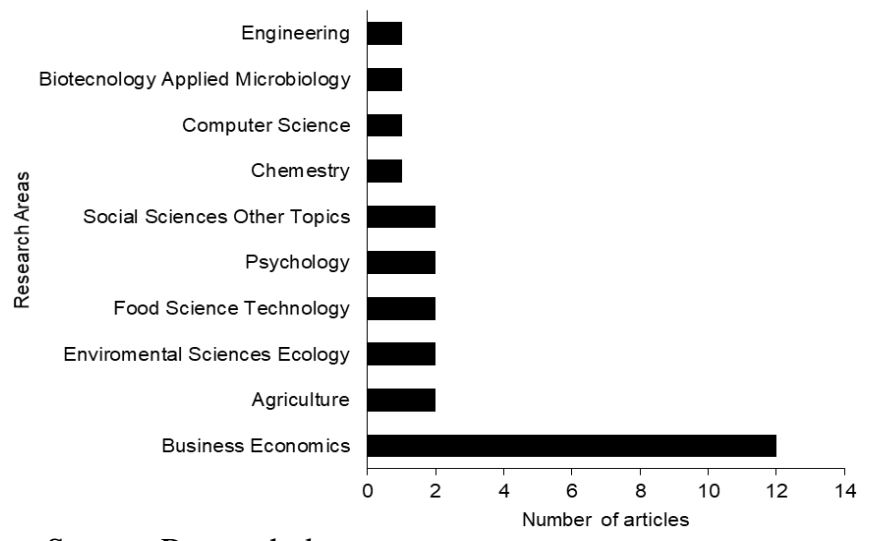

Source: Research data. 
Table 1

Academic production on elderly consumer behavior in the most frequently cited articles

\begin{tabular}{|c|c|c|c|c|c|}
\hline Title & Authors & Journal & Category & $\begin{array}{c}\text { Number } \\
\text { of } \\
\text { citations }\end{array}$ & Countries \\
\hline $\begin{array}{l}\text { Decision make and brand } \\
\text { choice by older consumers }\end{array}$ & $\begin{array}{l}\text { [13] Cole et al. } \\
\text { (2008) }\end{array}$ & Marketing Letters & $\begin{array}{l}\text { Business / } \\
\text { Economics }\end{array}$ & 44 & $\begin{array}{l}\text { United } \\
\text { States / } \\
\text { France }\end{array}$ \\
\hline $\begin{array}{l}\text { High-Risk Food Consumption } \\
\text { and Food Safety Practices in a } \\
\text { Canadian Community }\end{array}$ & $\begin{array}{l}\text { [23] Nesbitt et } \\
\text { al. (2009) }\end{array}$ & $\begin{array}{l}\text { Journal of Food } \\
\text { Protection }\end{array}$ & $\begin{array}{l}\text { Food Science } \\
\text { Technology }\end{array}$ & 36 & Canada \\
\hline $\begin{array}{l}\text { A model of hygiene practices } \\
\text { and consumption patterns in the } \\
\text { consumer phase }\end{array}$ & $\begin{array}{l}{[24]} \\
\text { Christensen et } \\
\text { al. (2005) }\end{array}$ & Risk Analysis & $\begin{array}{l}\text { Food Science } \\
\text { Technology }\end{array}$ & 30 & Denmark \\
\hline $\begin{array}{l}\text { Luxury purchasing among older } \\
\text { consumers: exploring } \\
\text { inferences about cognitive age, } \\
\text { status, and style motivations }\end{array}$ & $\begin{array}{l}\text { [21] Amatulli } \\
\text { Guido and } \\
\text { Nataraajan } \\
\text { (2015) }\end{array}$ & $\begin{array}{c}\text { Journal of Business } \\
\text { Research }\end{array}$ & $\begin{array}{l}\text { Business / } \\
\text { Economics }\end{array}$ & 27 & $\begin{array}{l}\text { Italy / } \\
\text { United } \\
\text { States }\end{array}$ \\
\hline $\begin{array}{l}\text { A behavioral model of the } \\
\text { elderly internet consumer: a } \\
\text { case study }\end{array}$ & $\begin{array}{l}\text { [19] Kuo, Chen } \\
\text { and Chen } \\
(2010)\end{array}$ & $\begin{array}{l}\text { International } \\
\text { Journal of } \\
\text { Innovative } \\
\text { Computing } \\
\text { Information and } \\
\text { Control }\end{array}$ & $\begin{array}{l}\text { Business / } \\
\text { Economics }\end{array}$ & 22 & Taiwan \\
\hline $\begin{array}{l}\text { Virtual shopping and } \\
\text { unconscious persuasion: The } \\
\text { priming effects of avatar age } \\
\text { and consumers' age } \\
\text { discrimination on purchasing } \\
\text { and prosocial behaviors }\end{array}$ & $\begin{array}{l}\text { [22] Yoo, Peña } \\
\text { and } \\
\text { Drumwright } \\
(2015)\end{array}$ & $\begin{array}{l}\text { Computers in } \\
\text { Human Behavior }\end{array}$ & $\begin{array}{l}\text { Computer } \\
\text { Science / } \\
\text { Business } \\
\text { Economics }\end{array}$ & 11 & $\begin{array}{l}\text { South } \\
\text { Korea / } \\
\text { United } \\
\text { States }\end{array}$ \\
\hline
\end{tabular}

Source: Research data

The other articles were included in categories such as Food Science Technology (two), Environmental Studies (two), Agronomy (one), Applied Microbiology Biotechnology (one), Applied Chemistry (one), Physical Chemistry (one), Artificial Intelligence Computer Science (one), Chemical Engineering (one), among others.

In general, the developed studies have sought to understand the behavior and perception of the elderly in relation to credit consumption, some types of food, products related to mobility, household technologies, clothing, among others.

It is noteworthy that given the population aging phenomenon and its implications in several areas, including consumption, studies that aim to understand how the contemporary elderly consumers behave are important and necessary.

In relation to co-authorship, 95\% of the articles were written in partnerships ranging from two to nine researchers. In terms of partnerships among authors from different countries, it is important to highlight the United States of America and France, and the United States of America and South Korea. However, most of the studies on elderly consumer behavior have been developed without foreign cooperation.
Keyword counting is usually a part of studies on scientific production. The most frequent keywords used were "consumer behavior" (five), "consumption" (five), "information" (four), and "elderly" (three). When entirely analyzing the articles, and establishing the minimum occurrence of two terms, 234 terms were found. Among these, 22 were related to each other in the studies. Fig. 8 shows the four clusters formed by these terms.

Fig. 7

Categories related to elderly consumer behavior

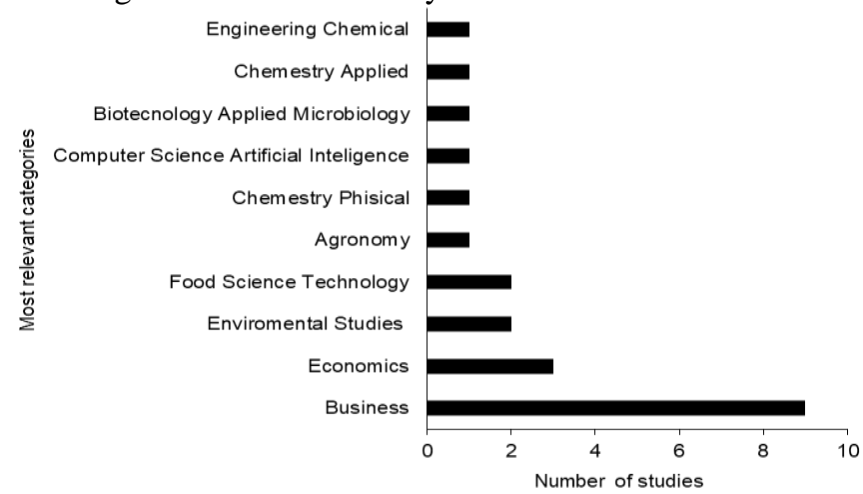

Source: Research data. 
Fig. 8

Clusters related to the descriptors consumer behavior and elderly

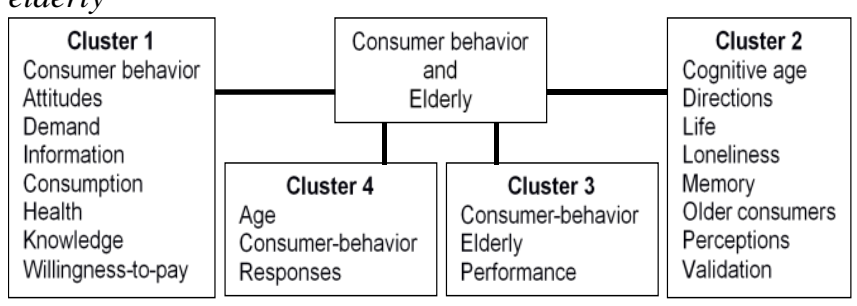

Source: Research data.

Cluster 1 is focused on health, demands, and consumption of elderly consumers. Clusters 2, 3, and 4 are related to the same theme, namely "behavior of the elderly consumer". This study confirmed that research regarding to understand the purchase behavior of the elderly consumer began when the elderly people started to be considered as a potential consumer group, attracting the attention of professionals and researchers in the areas of marketing and advertising, although it is still an incipient theme.

Fig. 9 demonstrates the network formed by the occurrence of keywords according to the descriptors "consumer behavior" and "elderly". The network formed in Fig. 9 appears to be more open and less intertwined. This information reinforce that there were few published scientific studies on elderly consumer behavior.

The United States of America stands out among the countries that have developed research on the subject under analysis. Together with France and South Korea the three countries formed a network. The United States of America is also the country that has the largest number of partnerships with researchers from other countries. That can be explained because countries as the United States of America, France, and other from Europe have already completed their age structure transition processes. The United States' elderly population doubled in 2012 and it took 77 years for this transition to happen. It took France 110 years to double its relative share of elderly (1870-1980). In the same idea, South Korea took only 18 years to double its elderly population, which occurred in 2017 [25].

Fig. 9

Co-occurrence of the most relevant terms on elderly consumer behavior

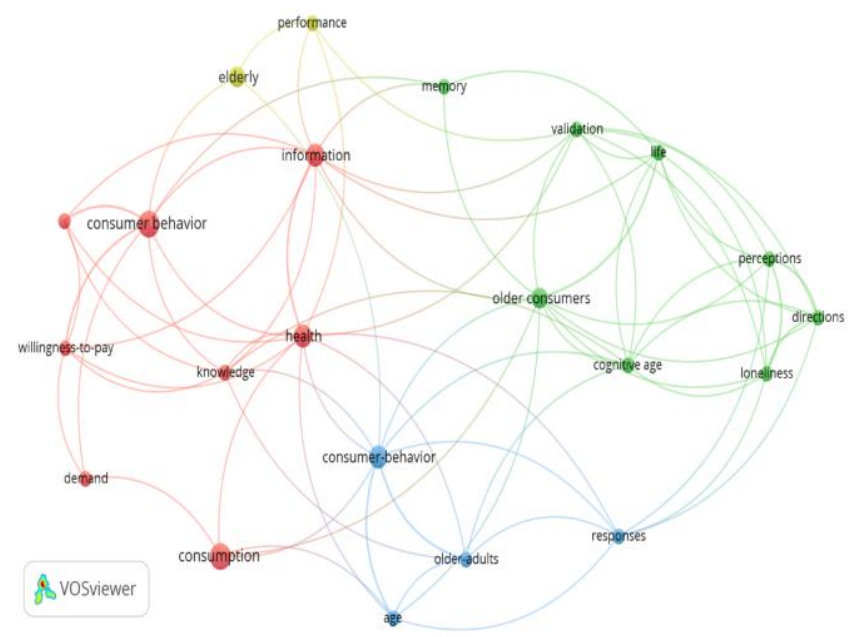

Although South Korea has recently completed the transition in its age structure, the country has been emerging in the number of publications on the researched topic. This allows us to infer that these countries have been concerned with the ageing issue. Therefore, they started their research on population aging before other countries.

Other countries, such as Japan, Israel, Mexico, Canada, Brazil, Norway, and Denmark have also developed researches, however, in a smaller frequency and in an isolated way. They did not form partnership networks with foreign researchers, which is the reason for their absence on the mentioned network.

Fig. 10 demonstrates the network of institutions that have developed and published studies on the behavior of elderly consumers since 2001.

Fig. 10 also demonstrates that the network formed by teaching and research institutions was composed of only nine institutions among the 31 that have already developed and published articles on elderly consumer behavior. Among these institutions, 54\% were from the United States of America, and 36\% from France. South Korea did not make up the network of institutions, although it is one of the countries that stood out in number of publications on the subject. The number of publications from institutions that have a foreign co-authorship is still not significant when compared to the institutions in the USA and France.

Although studies on the elderly consumer behavior have been developed with an economics focus, these were still in fewer number. Further studies with this focus are important to understand how the elderly consumer allocates his/her income considering the monthly household expenses, the products that burden their budget, and the overriding factors in the purchase decision. As so, governments and companies would be able to plan policies, develop products and strategies that support the needs of the elderly consumer.

Fig. 10

Network of institutions that have developed research on the behavior of elderly consumers

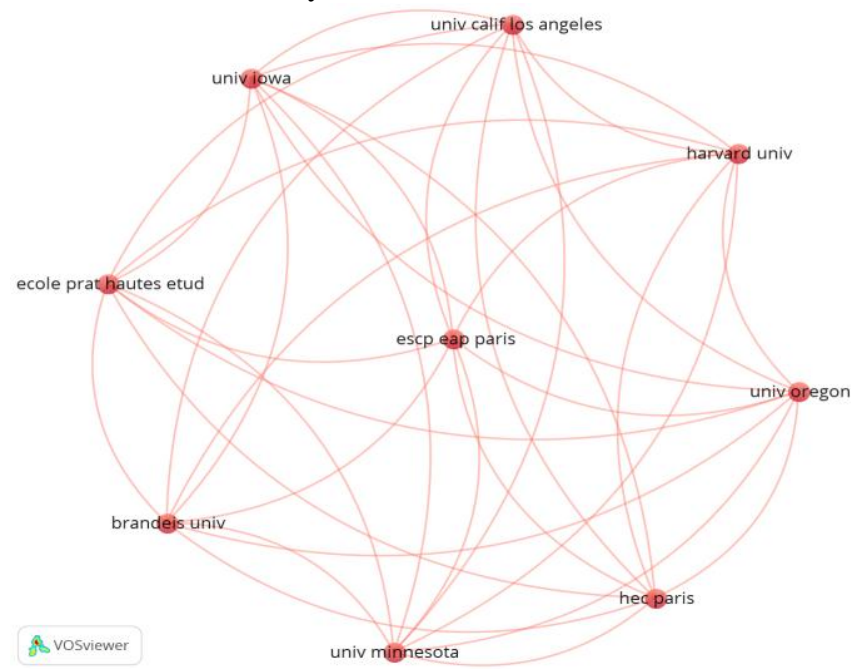

Source: Research data.

Source: Research data. 


\section{CONCLUSION}

The main contribution of this study is to use the meta-analysis to investigate the studies related to the consumption patterns and consumption behavior of the elderly people. The results have suggested that there are few studies regarding the consumption pattern. Regarding the elderly consumers behavior, there is a slightly larger number of studies, with an economic focus. However, this number of studies is still not expressive. Most of the studies were developed in the business area, followed by economics.

Considering the global phenomenon of population aging, the exponential increase in the number of elderly people will bring social and economic implications and transformations. One of these implications is related to consumption. The elderly people form a considerable market niche with potential for purchase. And this niche is not only emerging, but also will need to have its demands and needs met. It is necessary that the government and companies develop policies, strategies, actions, and products to this age segment. In this sense, studies that aim to understand the elderly consumer, their different needs, how they manage their family budget and monthly expenses are relevant to create and implement public policies to support this population.

We suggest that future studies should expand the research to other databases, with a more comprehensive time frame. It is also important to develop a more in-depth analysis seeking an in-depth understanding of the networks among authors, countries, and journals to verify the characteristics and changes in the elderly consumers behavior over time and cultures.

\section{REFERENCES}

[1] H. L. Meadow, S. C. Cosmas, A Plotkin, "The elderly consumer: Past, present, and future," Advances in Consumer Research, vol. 8, 1981, pp 742-747.

[2] N. C. V. de Melo, K. M. D. Teixeira, M. B. Silveira. (2017). Consumo e perfil social e demográfico dos diferentes arranjos domiciliares de idosos no Brasil: análises a partir dos dados da Pesquisa de Orçamentos Familiares. Revista Brasileira de Geriatria e Gerontologia [Online]. 20(5) pp. 607-617. Available: https://doi.org/10.1590/1981-22562017020.170047

[3] B. Ying, R. Yao. (2010). Self-perceived age and attitudes toward marketing of older consumers in China. Journal of Family Economics Issues [Online]. 31 pp. 318-327. Available: https://doi.org/10.1007/s10834-010-9199-y

[4] B. Ying, R Yao. (2006). Consumption patterns of Chinese elders: Evidence from a survey in Wuhan, China. Journal of Family and Economics Issues [Online]. 27 pp. 702-714. Available: https://doi.org/10.1007/s10834-006-9032-9

[5] W. Huang, Y. J. Lin, H. F Lee. (2019). Impact of Population and Workforce Aging on Economic Growth: Case Study of Taiwan. Sustainability [Online]. 11, pp. 6301. Available: https://doi.org/10.3390/su11226301

[6] V. R. Kivett, F. N. Schwenk. (1994). The consumer expenditures of elderly women: Racial, marital, and rural/urban impacts. Journal of Family and Economics Issues [Online]. 15 pp. 261-277. Available: https://doi.org/10.1007/BF02353631

[7] Instituto Brasileiro de Informação em Ciência e Tecnologia, Tutorial Software VOSviewer. (2018).

[8] G. Naegele, "Consumer-behavior of elderly - Possibilities and limitations of an age-related consumer policy," Zeitschrift für Gerontologie, 1978, pp. 283-284.
[9] N. N. L. da Silva, M. P. Xavier, “A terceira idade como foco das propagandas midiáticas de consumo," Psicologia Revista, 2012, vol. 21(2), pp. 203-215.

[10] F. C. A. Carvalho, D. E. Rosseto, F. M. Borini, J. C. B. Figueiredo. (2015). Capacidade absortiva e inovação: Um panorama da produção científica internacional entre 1990-2015. Anais do Simpósio Internacional de Gestão de Projetos, Inovação e Sustentabilidade [Online]. Available: http://www.singep.org.br/4singep/resultado/667.pdf

[11] B. M. Ássimos, G. T. Almeida, G. L. Batinga, M.R. Pinto. (2018) Credit consumption as a gift expression under the perspective of low-income elderly. Brazilian Journal of Marketing - BJM [Online]. 17(6) pp. 914-930. Available: https://doi.org/10.5585/bjm.v17i6.3848

[12] M. Ben-Ami, J. Hornik, D. Eden, O. Kaplan. (2014). Boosting consumers' self-efficacy by repositioning the self. European Journal of Marketing [Online]. 48(11/12) pp. 1914-1938. Available: https://doi.org/10.1108/EJM-09-2010-0502

[13] C. Cole, G. Laurent, A. Drolet, J. Ebert, A. Gutchess, R. Lambert-Pandraud, E. Mullet, M. I. Norton, E. Peters. (2008). Decision making and brand choice by older consumers. Marketing Letters [Online]. 19 pp. 355-365. Available: https://doi.org/10.1007/s11002-008-9058-x

[14] M. M. Khan, H. Asad, I. Mehboob. (2017). Investigating the consumer behavior for halal endorsed products: Case of an emerging Muslim market. Journal of Islamic Marketing [Online]. 8(4) pp. 625-641. Available: https://doi.org/10.1108/JIMA-09-2015-0068

[15] R. Nonomura. (2017). Political consumerism and the participation gap are boycotting and 'buycotting' youth-based activities? Journal of Youth Studies [Online]. 20(2) pp. 234-251. Available: https://doi.org/10.1080/13676261.2016.1206861

[16] M. Pannhorst, F. Dost. (2019). Marketing innovations to old-age consumers: A dynamic Bass model for different life stages. Technological Forecasting \& Social Change [Online]. 140 pp. 315-327. Available: https://doi.org/10.1016/j.techfore.2018.12.022

[17] S. Roy, S. N. Sanyal. (2017). Perceived consumption vulnerability of elderly citizens: A qualitative exploration of the construct and its consequences. Qualitative Market Research: An International Journal [Online]. 20(4) pp. 469-485. Available: https://doi.org/10.1108/QMR-11-2016-0113

[18] J. D. Ketcham, N. V. Kuminoff, C. A. Powers. (2015, July). Which models can we trust to evaluate consumer decision making? Comment on "choice inconsistencies among the elderly". National Bureau of Economic Research [Working Paper No 21387]. Available: https://doi.org/10.3386/w21387

[19] H. Kuo, C. Chen, C. Chen, "A behavioral model of the elderly internet consumer: a case study," International Journal of Innovative Computing, Information and Control, vol. 6(8), 2010, pp. 3507-3518.

[20] S. Nakano, A. Washizu. (2017). Changes in consumer behavior as a result of the Home Appliance Eco-Point System: an analysis based on micro data from the Family Income and Expenditure Survey. Environmental Economics Policy Studies [Online]. 19 pp. 459-482. Available: https://doi.org/10.1007/s10018-016-0145-6

[21] C. Amatulli, G. Guido, R. Nataraajan. (2015). Luxury purchasing among older consumers: exploring inferences about cognitive age, status, and style motivations. Journal of Business Research [Online]. 68(9) pp. 1945-1952. Available: https://doi.org/10.1016/j.jbusres.2015.01.004

[22] S. Yoo, J. F. Peña, M. E. Drumwright. (2015). Virtual shopping and unconscious persuasion: The priming effects of avatar age and consumers' age discrimination on purchasing and prosocial behaviors. Computers in Human Behavior [Online]. 48 pp. 62-71. Available: https://doi.org/10.1016/j.chb.2015.01.042

[23] A. Nesbitt, S. Majowicz, R. Finley, B. Marshall, F. Pollari, J. Sargeant C. Ribble, J. Wilson, N. Sittler. (2009). High-risk food consumption and food safety practices in a canadian community. Journal of Food Protection [Online]. 72(12) pp. 2575-2586. Available: https://doi.org/10.4315/0362-028x-72.12.2575

[24] B. B. Christensen, H. Rosenquist, H. M. Sommer, N. L. Nielsen, S. Fagt, N. L. Andersen, B. Nørrung. (2005). A model of hygiene practices and consumption patterns in the consumer phase. Risk Analysis [Online]. 25(1) pp. 49-60. Available: https://doi.org/10.1111/j.0272-4332.2005.00566.x

[25] J. E. D Alves. (2017). As diferentes velocidades do envelhecimento populacional. Revista Ihu on-line [Online] pp. 537. Available: http://www.ihu.unisinos.br/78-noticias/574267-as-diferentes-velocida des-do-envelhecimento-populacional 